\title{
Immunomodulating Effect of Methisoprinol on the Pronephros Macrophage and Lymphocyte Activity after Suppression Induced by Infectious Haematopoietic Necrosis Virus (IHNV) in Rainbow Trout (Oncorhynchus mykiss)
}

\author{
A. K. SIWICKI ${ }^{1,2}$, J. MAŁACZEWSKA ${ }^{1}$, B. KAZUN² 2 R. WÓJCIK \\ ${ }^{1}$ Department of Microbiology and Clinical Immunology, Faculty of Veterinary Medicine, \\ University of Warmia and Mazury, Olsztyn, Poland \\ ${ }^{2}$ Department of Fish Pathology and Immunology, Inland Fisheries Institute in Olsztyn, Poland \\ Received March 17, 2008 \\ Accepted July 7, 2008
}

\begin{abstract}
Siwicki A. K, J. Małaczewska, B. Kazun, R. Wójcik: Immunomodulating Effect of Methisoprinol on the Pronephros Macrophage and Lymphocyte Activity after Suppression Induced by Infectious Haematopoietic Necrosis Virus (IHNV) in Rainbow Trout (Oncorhynchus mykiss). Acta Vet. Brno 2008, 77: 631-635.

The purpose of this in vitro study was to determine the influence of methisoprinol on the activity of pronephros macrophages and lymphocytes after suppression induced by infectious haematopoietic necrosis virus (IHNV). For this study IHNV-free rainbow trout were used. Pronephros from 20 fish were removed and single leukocyte suspensions were separated. The IHNV significantly $(P<0.05)$ decreased the respiratory burst activity and potential killing activity of pronephros macrophages and proliferative response of lymphocytes stimulated by mitogens ConA and LPS. The results of our in vitro study showed that methisoprinol at a concentration of $50 \mathrm{mg} / \mathrm{ml}$ modulated (restored) the metabolic and potential killing activity of macrophages and proliferative response of lymphocytes suppressed by IHNV.
\end{abstract}

In vitro study, phagocyte activity, lymphocyte proliferation

Rhabdoviruses constitute one of the largest groups of viruses isolated from fish, and are mostly associated with epizootics and heavy losses in intensive fish farming. Infectious haematopoietic necrosis (IHN) is the most important viral disease and produces high losses in rainbow trout and other salmon species farmed in North America and in several European countries. Infectious haematopoietic necrosis virus (IHNV) is a member of Rhabdoviridae and the type species of the genus Novirhabdovirus. Like other mononegavirales, it has a single molecule of linear, negative-sense ssRNA genome (Kurath et al. 1997). The multiplication of virus takes place in endothelial cells of blood capillaries leading to haemorrhages in haematopoietic tissues and nephron cells (Amend and Smith 1974). The transmission of IHNV takes place horizontally, vertically, and by biological vectors such as fish parasites. Acutely infected fish release the virus by external mucus, faeces and urine. Carriers shed the agent via sexual products (Kim et al. 1999).

The protection against viral diseases by specific vaccines against IHN is being developed for the last few years (Corbeil et al. 2000; Lorenzen et al. 2002; Prost 2003) and some successful vaccines have been developed (Purcell et al. 2006; Miller et al. 2007). Rodriguez Saint-Jean and Perez-Prieto (2007) examined the ability of several fish viruses to induce protection against homologous or heterologous viruses in single or double infections, and assessed whether such protection is correlated with innate immunity or expression of the $M x$ gene. The results of this study indicate that activation of the immune response could explain the interference and loss of IHNV in the IPNV-IHNV co-infections. In fact, the DNA vaccines against IHN virus only have a scientific aspect and the application of these vaccines in rainbow trout culture is

Address for correspondence:

Andrzej K. Siwicki

Zabieniec near Warsaw

05-500 Piaseczno

POLAND

E-mail: aksiw@infish.com.pl

http://www.vfu.cz/acta-vet/actavet.htm 
limited. However, for an ideal preventive approach, specific drugs should be developed to inhibit selectively virus replication or to stimulate the antiviral protection. The use of natural and synthetic immunomodulators in fish offers a wide range of attractive methods for inducing and building up protection against viral diseases and is a promising new development in aquaculture (Anderson 1992; Siwicki et al. 1998). Several promising drugs and biological response modifiers such as carbohydrates and other synthetics have been tested on fish immunocompetence cells in vitro. A dosedependent immunomodulatory effect of levamisole, nitrogranulogen, lysozyme dimer and HMB were observed on macrophage activity, proliferative response of lymphocytes and antibody secreting cells in rainbow trout and other fish species (Siwicki et al. 2003; Terech-Majewska et al. 2004; Siwicki et al. 2006).

Methisoprinol is a synthetic compound formed from the p-acetamidobenzoate salt of N-N-dimethylamino-2-propanol and inosine in a $3: 1$ molar ratio. Methisoprinol presents low toxicity and has been shown to act in vitro by inhibiting the replication of salmonid rhabdoviruses (Siwicki et al. 2002). It exerts antiviral and antitumour activities in vitro and in vivo, which are secondary to the immunomodulating influence on non-specific cellular and humoral defence mechanisms and protection against viral diseases (Delogu et al. 1982; Fudenberg and Whitten 1984; Siwicki et al. 2003).

The aim of the present study was to determine the in vitro influence of methisoprinol on the pronephros macrophage and lymphocyte activity after suppression induced by infectious haematopoietic necrosis virus (IHNV) in rainbow trout (Oncorhynchus mykiss).

\section{Materials and Methods}

In this in vitro study 20 healthy (IHNV-free) rainbow trout (Oncorhynchus mykiss) with a mean weight of $50 \mathrm{~g}$ were used. The fish were held in a 5001 tank in $14{ }^{\circ} \mathrm{C}$ spring water and fed twice daily with commercial pellets. The pronephros were removed from fish aseptically and single leukocyte suspensions were separated on Histopaque-1077 (Sigma, USA) gradient or Gradisol (Polfa, Poland), according to the method presented by Siwicki et al. (1996). Viable cells from the pronephros were counted with $0.1 \%$ of trypan blue staining after washing three times in RPMI 1640 medium, and 90-94\% of cell vitality were ascertained. The Laboratoire Departemental d'Analyses France (LDA 39) IHNV isolate was used in this in vitro study and quantified by plaque assay using epithelioma papulosum cyprini (EPC) cells incubated at $14^{\circ} \mathrm{C}$ for $72 \mathrm{~h}$.

Methisoprinol (Polfa Grodzisk, Poland) was used at a concentration of $50 \mathrm{mg} / \mathrm{ml}$ of RMPI-1640 medium (Sigma).

The spectrophotometric assay presented by Siwicki et al. (1996) was used to study the respiratory burst activity of pronephros macrophages stimulated by phorbol myristate acetate (PMA, Sigma). One hundred $\mathrm{ml}$ of cell suspension $\left(1 \times 10^{6}\right.$ in RPMI-1640) were added to 96-well culture plates (Nunclon, Denmark) and incubated for $2 \mathrm{~h}$ at $22{ }^{\circ} \mathrm{C}$ with $50 \mathrm{ml}$ of methisoprinol or $50 \mathrm{ml}$ of $1 \times 10^{7}$ plaque-forming units/ml RPMI-1640 of IHN virus or with $50 \mathrm{ml}$ of IHN virus $+50 \mathrm{ml}$ of methisoprinol. The control group comprised cells only stimulated by PMA.

The potential killing activity of pronephros macrophages was determined with a microcolorimetric method presented by Anderson and Siwicki (1994). The $0.2 \%$ nitroblue tetrazolium (NBT, Sigma, USA) in PBS solution containing live $1 \times 10^{7}$ Aeromonas salmonicida cells was used for stimulation of pronephros macrophages. The cells $\left(100 \mathrm{ml}\right.$ ) were added to 96 -well culture plates (Nunclon, Denmark) and incubated for $30 \mathrm{~min}$ at $22^{\circ} \mathrm{C}$ with $50 \mathrm{ml}$ of methisoprinol or $1 \times 10^{7}$ plaque-forming units/ml RPMI- 1640 of IHN virus or with $50 \mathrm{ml}$ of IHN virus $+50 \mathrm{ml}$ of methisoprinol. The control group comprised cells only stimulated by $0.2 \%$ NBT solution containing live bacteria A. salmonicida.

The proliferative response of pronephros lymphocytes was determined by the MTT [3-(4,5-dimethyl thiazol2-yl)-2,5-diphenyl tetrazolium bromide] assay described by Mosmann (1983), as modified for use with fish lymphocytes by Siwicki et al. (1996). Briefly, lymphocytes were isolated from pronephros and distributed $(100 \mathrm{ml})$ into 96 -well culture plates (Nunclon, Denmark) at $5 \times 10^{6} \mathrm{cell} / \mathrm{ml}$ of RPMI- 1640 . The mitogen concanavalin A (ConA, Sigma) at a concentration of $64 \mathrm{mg} / \mathrm{ml}$ or lipopolysaccharide (LPS, Sigma) at a concentration of $160 \mathrm{mg} / \mathrm{ml}$ was added $(20 \mathrm{ml})$ into each well. The cells were incubated for $72 \mathrm{~h}$ with $50 \mathrm{ml}$ of methisoprinol or $50 \mathrm{ml}$ of IHN virus $\left(1 \times 10^{7} \mathrm{pfu} / \mathrm{ml}\right)$ or with $50 \mathrm{ml}$ of IHN virus $+50 \mathrm{ml}$ of methisoprinol. The control group comprised cells only stimulated by mitogens: Con A or LPS.

The results were verified statistically by one-way ANOVA analysis of variance (GraphPad Prism software 
package), and the significance of differences between the groups verified with Bonferroni test. Differences between the means were considered significant if $P<0.05$.

\section{Results and Discussion}

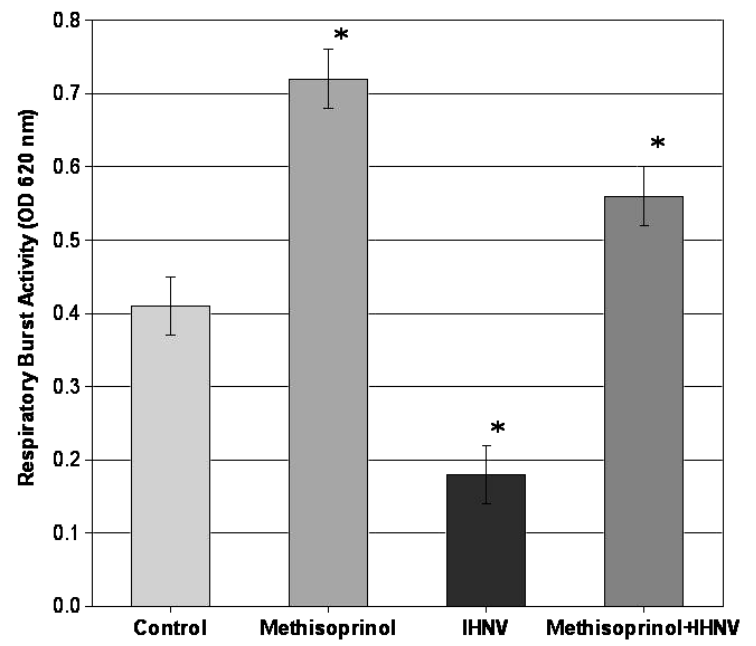

Fig. 1. In vitro immunomodulatory effect of methisoprinol on the pronephros macrophage respiratory burst activity (RBA) after suppression induced by $\mathrm{IHN}$ virus $(\mathrm{IHNV})(\mathrm{n}=20$, mean $\pm \mathrm{SD}$, * significant differences $P<0.05$ )

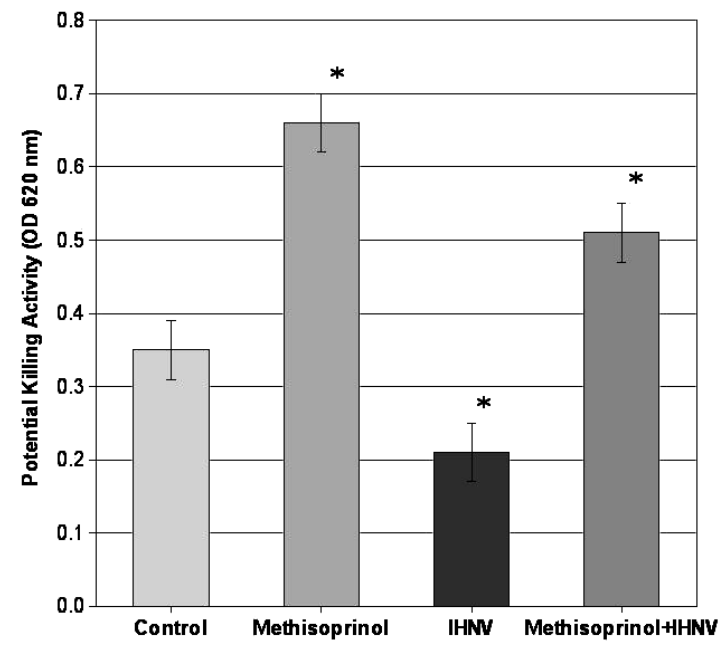

Fig. 2. In vitro immunomodulatory effect of methisoprinol on the pronephros macrophage potential killing activity (PKA) after suppression induced by IHN virus $(\mathrm{IHNV})(\mathrm{n}=20$, mean $\pm \mathrm{SD}$, * significant differences $P<0.05$ ) types involved in both rhabdovirus infections. It has been previously shown that rhabdoviruses replicate within the macrophages (Estepa et al. 1992).
The current study used an in vitro model to examine the influence of IHNV and methisoprinol on the pronephros macrophage and lymphocyte activity stimulated by mitogens. The aim of the first part of our study was to determine the in vitro effects of IHNV on the activity of pronephros macrophages and lymphocytes. As shown in Fig. 1 , the IHNV significantly decreased the metabolic activity of pronephros macrophages and potential killing activity of pronephros macrophages (Fig. 2). Similar pattern was observed with pronephric lymphocytes. The IHNV significantly decreased the proliferativeresponse oflymphocytes stimulated by mitogens ConA and LPS (Fig. 3).

The mechanisms involved in the establishment of rhabdovirus infections in fish are not well understood. Very few data have been obtained on the influence of IHNV on the cell-mediated immunity in fish (Amend and Smith 1974; La Patra et al. 1993). Chilmonczyk and Winton (1994) suggested that leukocytes may serve as target cells for the initial phase of IHNV infection. In our study we clearly demonstrated a suppressive effect of IHNV on the pronephros macrophage activity. This may have been due to an impairment of the phagocyte function. The disease may affect the phagocyte function, and particularly the respiratory burst activity and potential killing activity. The data obtained for IHNV corroborated those previously obtained with viral haemorrhagic septicaemia virus (VHSV) and confirmed that leukocytes represent one of the cell 


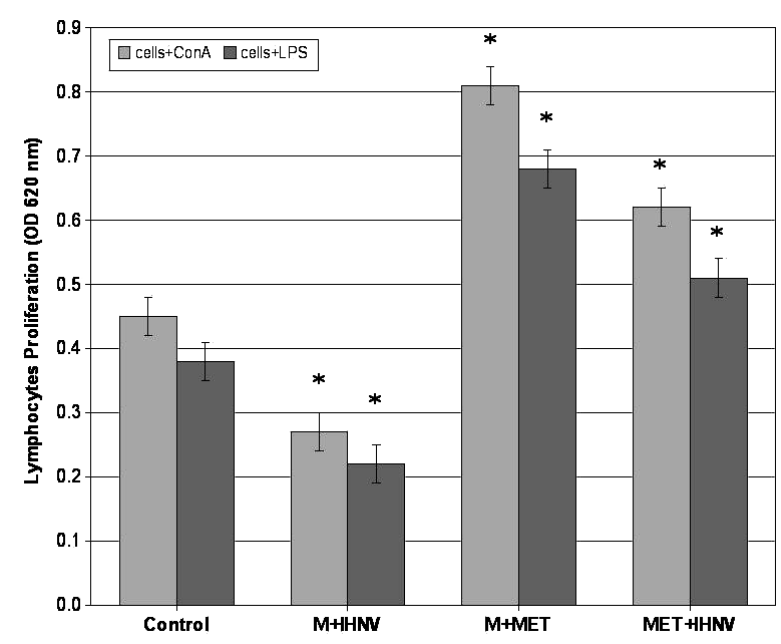

Fig. 3. In vitro immunomodulatory influence of methisoprinol (MET) on the proliferative response of pronephros lymphocytes stimulated by mitogens (M): ConA or LPS, after suppression induced by $\mathrm{IHN}$ virus $(\mathrm{IHNV})(\mathrm{n}=20$, mean $\pm \mathrm{SD}, *$ significant differences $P<0.05)$ stimulated by ConA and LPS after suppression induced by IHNV are presented in Fig. 3 . In this in vitro study we observed that methisoprinol modulated (restored) the macrophage and lymphocyte activity strongly suppressed by IHNV. The in vitro infection of cells by IHNV and incubation with methisoprinol significantly increased the metabolic activity and potential killing activity of pronephros macrophages, compared to the control cells and cells only infected by IHNV. Similar results were observed with proliferative response of lymphocytes infected by IHNV and incubated with methisoprinol (Fig. 3).

In this study we clearly demonstrated that methisoprinol stimulated the respiratory burst activity and potential killing activity of pronephros macrophages and proliferative response of lymphocytes stimulated by mitogens ConA and LPS. Also an immunomodulating influence of methisoprinol on the pronephros macrophages and lymphocytes after suppression induced by IHNV was observed. Similar results were observed with in vitro proliferative response of lymphocytes and macrophage activity infected by VHSV in rainbow trout and incubated with methisoprinol (Siwicki et al. 2003). The results of our in vitro study suggest that methisoprinol restores the function of phagocytes and lymphocytes suppressed by IHNV. These results and observations are important, especially in view of the possibility that this product could by used to eliminate the depressive influence of viral infection on the cell-mediated immunity responses. A future study will include determination of optimal doses and protocol of application of methisoprinol to maximise the in vivo immunomodulatory effects and protection against IHNV in rainbow trout.

\section{Imunomodulační účinky methisoprinolu na aktivitu makrofágů a lymfocytů pronefros po supresi zpưsobené virem infekční nekrózy hematopoetické tkáně (IHNV) u pstruha duhového (Oncorhynchus mykiss)}

Cílem této in vitro studie bylo určit vliv methisoprinolu na aktivitu makrofágů a lymfocytů pronefros po supresi způsobené virem infekční nekrózy hematopoetické tkáně 
(IHNV) s využitím pstruha duhového prostého IHNV (IHNV-free). Tkáň pronefros byla odebrána z 20 ryb pro získání suspenzí jednotlivých leukocytárních linií. Virus infekční nekrózy krvetvorné tkáně významně $(P<0.05)$ snižuje aktivitu oxidačního vzplanutí a zneškodnění cizorodého agens makrofágů pocházejících z pronefros a proliferativní odpověd' lymfocytů po stimulaci mitogeny ConA a LPS. Výsledky naší in vitro studie ukázaly, že methisoprinol v koncentraci $50 \mu \mathrm{g} / \mathrm{ml}$ reguluje (obnovuje) metabolickou a potenciální obrannou aktivitu makrofágů pro zneškodnění cizorodé agens a proliferativní odpověd' lymfocytů suprimovaných virem infekční nekrózy hematopoetické tkáně u pstruha duhového.

\section{References}

AMEND DF, SMITH L 1974: Pathophysiology of infectious haematopoietic necrosis virus disease in rainbow trout (Salmo gairdneri): early changes in blood and aspects of the immune response after injection of IHN virus. J Fish Res Bd Can 31: 1371-1378

ANDERSON DP 1992: Immunostimulants, adjuvants and vaccine carriers in fish: application to aquaculture. Annu Rev Fish Dis 2: 281-307

ANDERSON DP, SIWICKI AK 1994: Simplified assays for measuring nonspecific defence mechanisms in fish. Fish health section. American Fisheries Society Meeting, Seattle, WA, 26 p.

CHILMONCZYK S, WINTON JR 1994: Involvement of rainbow trout leucocytes in the pathogenesis of infectious haematopoietic necrosis. Dis Aquat Org 19: 89-94

CORBEIL S, KURATH G, LA PATRA SE 2000: Fish DNA vaccine against infectious haematopoietic necrosis virus: efficacy of various routes of immunisation. Fish Shellfish Immunol 10: 711-723

DELOGU G, LOZZI A, CAMPANELLI A, DE RITIS G, PIETROPAOLI P 1982: Cell-mediated immunity and immunomodulatory drugs in critically ill patients. Acta Anaesthesiol Ital 33: 619-625

ESTEPA A, FRIAS D, COLL JM 1992: Susceptibility of trout kidney macrophages to viral hemorrhagic septicemia virus. Viral Immunol 4: 283-292

FUDENBERG HH, WHITTEN HD 1984: Immunostimulation: synthetic and biological modulators of immunity. Annu Rev Pharmacol Toxicol 24: 147-174

KIM CH, DUMMER DM, CHIOU PP, LEONG JAC 1999: Truncated particles produced in fish surviving infectious haematopoietic necrosis virus infections: mediators of persistence? J Virol 73: 843-849

KURATH G, HIGMAN KH, BJORKLUND HV 1997: Distribution and variation of NV genes in fish rhabdoviruses. J Gen Virol 78: 113-117

LA PATRA SE, TURNER T, LAUDA KA, JONES GR, WALKER S 1993: Characterization of the humoral response of rainbow trout to infectious haematopoietic necrosis virus. J Aquat Anim Health 5: 165-171

LORENZEN N, LORENZEN E, EINER-JENSEN K, LA PATRA SE 2002: DNA vaccines as a tool for analysing the protective immune response against rhabdoviruses in rainbow trout. Fish Shellfish Immunol 12: 439-453

MILLER K, TRAXLER G, KAUKINEN K, LI S, RICHARD J, GINTHER N 2007: Salmonid host response to infectious hematopoietic necrosis (IHN) virus: Cellular receptors, viral control, and novel pathways of defence. Aquaculture 272 (Suppl): 217-237

MOSMANN T 1983: Rapid colorimetric assay for cellular growth and survival: application to proliferation and cytotoxicity assays. J Immunol Methods 65: 55-63

PROST M 2003: Szczepionki genetyczne przeciw chorobom wirusowym ryb (Genetic vaccines against viral diseases in fish, in Polish). Med Weter 59: 564-567

PURCELL MK, NICHOLS KM, WINTON JR, KURATH G, THORGAARD GH, WHEELER P, HANSEN JD, HERWIG RP, PARK LK 2006: Comprehensive gene expression profiling following DNA vaccination of rainbow trout against infectious hematopoietic necrosis virus. Mol Immunol 43: 2089-2106

RODRIGUEZ SAINT-JEAN S, PEREZ-PRIETO SI 2007: Effect of salmonid fish viruses on Mx gene expression and resistance to single or dual viral infections. Fish Shellfish Immunol 23: 390-400

SIWICKI AK, KLEIN P, KICZKA W, MORAND M, STUDNICKA M 1996: In vitro effects of monomer and dimerized lysozyme on the polymorphonuclear (PMN) and mononuclear (MN) cells activity. In: Modulators of immune responses - the evolutionary trail. SOS Publications, Fair Haven, NJ, USA, pp. 221-232

SIWICKI AK, MORAND M, KLEIN P, STUDNICKA M, TERECH-MAJEWSKA E 1998: Modulation of nonspecific defence mechanisms and protection against diseases in fish. Acta Vet Brno 67: 323-328

SIWICKI AK, POZET F, MORAND M, KAZUŃ B, TRAPKOWSKA S 2002: In vitro effect of methisoprinol on salmonid rhabdoviruses replication. Bull Vet Inst Puławy 46: 53-58

SIWICKI AK, MORAND M, KAZUN B, TRAPKOWSKA S, POZET F 2003: In vitro immunomodulating influence of methisoprinol on the head kidney phagocyte and lymphocyte activity after suppression induced by VHSV in rainbow trout (Oncorhynchus mykiss). Pol J Vet Sci 6 (Suppl): 51-53 
SIWICKI AK, ZAKES Z, FULLER JC, NISSEN S, KAZUN K, GLABSKI E 2006: The influence of b-hydroxyb-methylbutyrate (HMB) on cell-mediated immunity in tench Tinca tinca (L.): in vitro and in vivo study. Aquac Int 14: 153-161

TERECH-MAJEWSKA E, SIWICKI AK, SZWEDA W 2004: Modulative influence of lysozyme dimer on defence mechanisms in the carp (Cyprinus carpio) and European sheatfish (Silurus glanis) after suppression induced by herbicide Roundup. Pol J Vet Sci 7: 123-128 